\title{
The Forgotten World War II Airfield: The Case of Morib Airfield
}

\author{
Wardatul Hayat Adnan¹, Dazmin Daud², MohdFarizi Jamaluddin³ \\ ${ }^{1}$ Faculty of Communication and Media Studies, UniversitiTeknologi MARA, Selangor, Malaysia \\ ${ }^{2}$ Faculty of Business and Management, UCSI University, Kuala Lumpur, Malaysia \\ ${ }^{3}$ Faculty of Social Sciences and Liberal Arts, UCSI University, Kuala Lumpur, Malaysia \\ *e-mail: wardatul@uitm.edu.my
}

Received: 28 May 2020; Accepted: 24 December 2020; Published: 02 January 2021

To cite this article (APA): Adnan, W. H., Daud, D., \& Jamaluddin, M. F. (2021). The Forgotten World War II Airfield: The Case of Morib Airfield. EDUCATUM Journal of Social Sciences, 7(1), 10-18. https://doi.org/10.37134/ejoss.vol7.1.2.2021

To link to this article: https://doi.org/10.37134/ejoss.vol7.1.2.2021

\begin{abstract}
The airfield site at Kelanang in Selangor, Malaysia was operated during World War II under the Japanese Occupation. During that time, it was noted for its air force surveillance centre which protected the area from Port Swettenham or previously known as Port Klang to Port Dickson. It also acted as a military logistics that planned and carried out the movement, supply, and maintenance of military forces to sustenance Morib area. Currently, this historical structure and its remains have no longer exist. The area has now been transformed to a palm oil plantation. As time goes by, this airfield has been forgotten and invisible to our young generation. In addition to that, there are lack of literature and studies about the history and its roles during and after World War II. This gap triggers this study on this airfield. Hence, the aim of the present study is to develop a literature review on the airfield. This includes to locate and to map the actual features of the airfield. To achieve this objective, field observation and in-depth interview were conducted. Official documents from the site location owners were obtained, as well as CIO HQ from air command centre in South East Asia Document was compiled to support the existence of the airfield. The findings from this study contribute towards the knowledge of this historical site, roles, and its contributions for the Government and public.
\end{abstract}

Keywords: World War II, Morib Airfield and Malaya Liberation

\section{INTRODUCTION}

In recent years, the Malaysia countryside has been the subject to an increasingly diverse array of development pressures in agriculture, property, and manufacturing. A new wave rural area policy has ensured that many proposed developments have been vociferously opposed due to lack of social and environmental consideration. The World War II airfields offer solution for current development pressures for agriculture and public settlement. This is because they comprise large flat terrain which are accessible and well maintain with a great deal of ready physical infrastructure (Gallent, Howe \& Bell, 2000). In addition, these sites can often be scrutinized as brownfield for future development (Adams, De Sousa \& Tiesdell, 2010).

The term airfield is a place where small size of airplanes can take off and land. It has only airstrip for landing and take-off purposes. In contrast of airport, the airfield does not require complex and huge infrastructures such as terminals or paved runaways. It usually has one runaway and basic facility. In the military logistics perspective, the decision to select the suitable location of the airfield is based on the terrain intelligence (Whitmore, 1960). This is to ensure that the airfield can sustain from the effect of the natural and man-made features on military operations. After the World War II ended in 1945, airfields are either in a situation of full or partial cessation of flying activity. 


\section{BACKGROUND OF STUDIES}

In the World War II, Japanese forces attacked Malaya in December 1941. By February 15, 1942, they occupied the entire Malaya and Singapore. During the occupation, as part of their military logistics, the Japanese built an airstrip at Morib for air force support to cover the perimeter from Port Swettenham (Port Klang) to Port kwas 49.39 miles or 79.52 kilometers (Morib Airfield - Port Swettenham: 14.32 miles / 23.04km; Morib Airfield - Port Dickson: 30.54 miles / 49.15km; Morib Airfield - Morib town: 4.55 miles $/ 7.33 \mathrm{~km}$ ) with approximately 102.06 miles square feet $/ 264.57 \mathrm{~km}$ square feet.

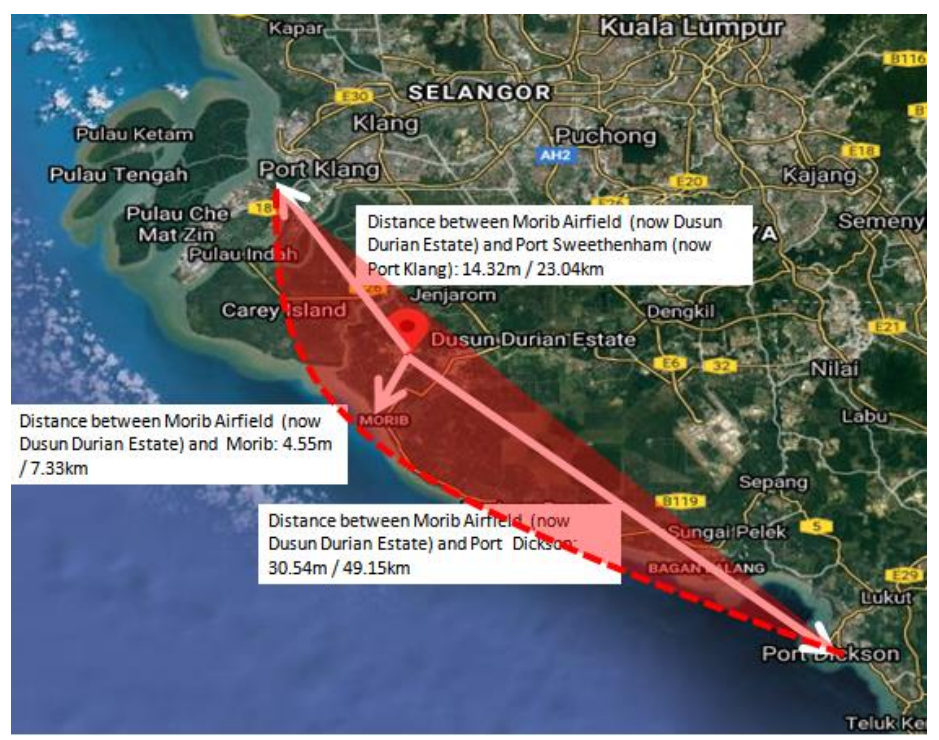

Figure 1: Coverage area for Japanese air force at Morib Airfield during World War II Source: Google Map

Throughout the end of the war, the Japanese was continually defeated by the Allies. During the liberation of Malaya from the Japanese occupation, the landing of the 23rd and 25th divisions of the British-aided Indian Army on Morib beach occurred on September 9, 1945 (Holder, 2005). When Allied forces landed at Morib beach, they did not encounter any resistance from the Japanese army. Once landed, their mission was to proceed to Kuala Lumpur. Located 10 kilometers from the Beach, the Allied forces occupied an airfield called Morib Airfield in Kelanang, Selangor.

Kelanang is an area in Kuala Langat district. It is located $8.8 \mathrm{~km}$ from Banting town. Majority of its population are Malays and Javanese. There is a small number of Indian and Chinese communities living in this town. The area was developed for settlement and agricultural activities in 1880s such as paddy, coconut, coffee, and local fruits (Tamrin, 1977). Figure 2 shows the recent location of Kelanang area which has witnessed this forgotten evidence of World War II Airstrip.

Currently, there is a lot of information about the landing of Allied forces at Morib beach, Selangor on September 9, 1945 for the liberation of Malaya from the Japanese. This gives an initial impression to generate a more comprehensive and detailed study especially on the Morib Airfield. Despite a lot of information about the landing and the liberation of Malaya, there is still little information about the airfield. A study specifically about the airfield and its current condition has not been studied. Furthermore, the information on the airfield is mainly from books and not from research studies. Information from these books merely focus on the taking over of the airfield by the Allied forces from the Japanese army (see writings from Grehan and Mace, 2014; Bose, 2012; Warwick, 2007; Holder, 2005; David, 2000).

In the London Gazette, a summary of the Allied forces that landed on Morib, had highlighted the airfield (London Gazzette, 1951). However, the term used was "Kelanang airfield" and not "Morib airfield". The Gazette stated that the Allied forces moved ashore from Morib to the Kelanang airfield on $10^{\text {th }}$ September 1945 before proceeded to Telok Datok on $14^{\text {th }}$ September 1945 . Meanwhile, there was an article from the Royal Engineers Journal volume 61 that highlighted the airfield. Price and 
Robertson (1947) wrote that the first objective of the landings in Malaya in September 1945 was to secure strategic areas of Port Swettenham (now Port Klang), Kelanang airfield and crossing of the coastal road over the Sepang River. This showed that the British forces wanted to secure the sea, air and road near the landing sites.

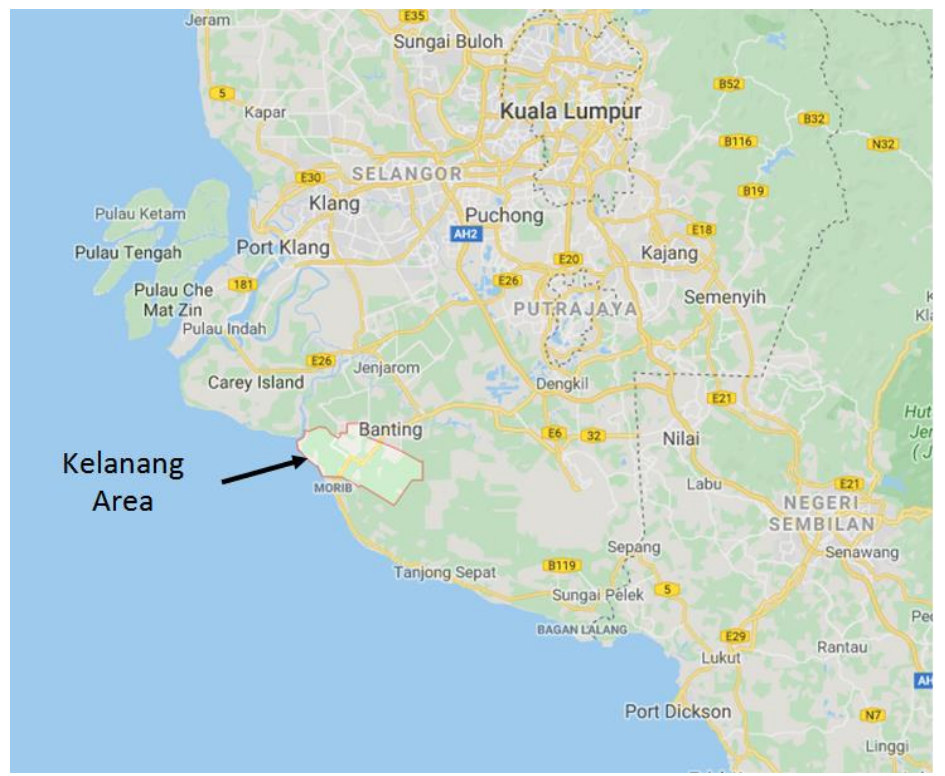

Figure 2: Map of Kelanang area in Selangor State Source: Google Map

Besides information from books, there are also information about the airfield from newspapers. The information only focused on one incident that occurred in September 1947, where there was an activity performed by the British army to clear the airfield from the World War II mortar bombs (see Singapore Free Press, 1947; Malaya Tribune, 1947; Morning Tribune, 1947).

It can be argued here that a study about Morib Airfield is still unexplored. Previous literature is mainly from books and newspapers but not from the academic literature. It is noted that the aspects of study from the academic perspective and the current condition of the airfield have not given much attention. Therefore, this study has chosen Morib Airfield as the research scope since the information about it is limited from the previous literature.

Hence, this article has three objectives:

- To develop a literature review of Morib Airfield during and after World War II;

- To provide a general view about the current land use of the Morib Airfield; and

- To match the narratives from respondents with the secondary data about the Morib Airfield and its relation to World War II.

\section{METHODOLOGY}

In this study a qualitative method was used. To be more specifically, library and field methods were applied. The library method is a method of collecting information from secondary sources from theses, journals, academic and non-academic texts, and materials related to Morib or Kelanang Airfield. It aims to understand and make comparisons from previous studies on the aspects to be studied (Chelaeh et. al, 2017). Meanwhile, for the field method, a method from Lawrenz, Keiser and Lavoie (2003) had been adopted. The aim is to pool a first-hand information about about the object understudied, in this case is the Morib Airfield.

In addition, an in-depth interview was conducted with three (3) respondents who have significant knowledge or information pertaining to the mentioned site. This method was used to verify 
information from written secondary sources. The three respondents involved in the present study have an average of 20 to 30 years experience working at the site.

\section{Site Description}

The Morib Airfield in Kelanang area, $71 \mathrm{~km}$ from Kuala Lumpur see Figure 1, was established during World War II. During the war, the Japanese had constructed an airfield for their Mitsubishi A6M Zero fighter aircraft. The airfield only served a few Zero aircrafts, hangars, and barracks. The location of the airfield was about $1 \mathrm{~km}$ from the Kelanang-SimpangMorib and Kampung Sungai Arak trunk road. It was surrounded by coconut trees at that time and therefore a suitable location for air traffic control and surveillance on the coast between Port Swettenham (precently known as Port Klang) and Port Dickson.

Furthermore, it was used as an air support for the Japanese army base at Morib. In the campaign of Malaya liberation, Morib Airfield was handed over peacefully by the 100 Japanese soldiers assigned to guard it to the Allied forces on September 9, 1945 (Warwick, 2007). It was found to be in good condition for further air force operation. After the smooth handover, the British Royal Air Force established an air force squadron on the airfield by evening of September 9, 1945. The airfield was considered as the important facility that must be captured first before Allied forces of World War II could march to Kuala Lumpur. It aims was to establish the first air strip immediately after the landings from the sea. Once the airfield was secured, the Allied forces set up communications, radar screens and several units of Spitfires made ready for action (Grehan \& Mace, 2014).

The former airfield is currently located at $2.8012^{\circ} \mathrm{N}, 101.4617^{\circ} \mathrm{E}$ in a palm oil plantation. This palm oil plantation is called the Dusun Durian estate and it has been in operation since 1954. Prior to 1954, the main plantation was rubber trees and the estate belonged to Harrisons \& Crosfield Plc until 1905. The estate later had transferred ownership for several times: Golden Hope Rubber Estate (1905 to 1982), Golden Hope Plantation Berhad (1982 to 2007), and today it is own by Sime Darby Plantation Sdn. Bhd. (2007 - present). Geographically, the terrain of the estate is flat (Ross, 2011) and the estimate terrain elevation above sea level is 18 meters. Furthermore, the groundwater has low concentrations of Total Suspended Solids (TSS) of outflow. Thus, from the air transport point of view, it was a strategic location for an air base (Vincent \& Jennings, 2004).

\section{Interviews for Selection of Sampling Sites}

In order to reduce the area of possible interest regarding the mapping of the Morib Airfield location, a set of in-depth interviews were conducted. This procedure was done because the present geographical area carries very little resemblance to an airfield. It is therefore giving a clearer understanding of the causal mechanisms that lead to breakdown of abstract points (Bennet \& Elman, 2006). There are six respondents who participated in the in-depth interview. Questions for the in-depth interview were validated by experts in the Social Science field.

All respondents were initially approached through a formal contact from a private commercial palm oil estate where the airfield is currently located. They are from the second generation who has been staying and working in the estate since 1952, 1962 and 1967 respectively. The interview was conducted on December 13, 2019. The main information provided by the interviews regarded (a) knowing the Morib Airfield during and after the World War II; (b) functions of the airfield during Japanese occupation and after the World War II ends; and (c) sources from respondents about the airfield. This procedure helps the authors to discover ironic descriptive data from those who are being exposed to the primary sources of the airfield information. To ensure the session is flexible, the interview was conducted in the form of general to a specific topic. The interviews were recorded in a form of videography, and notes were taken for data analysis purposes as per agreed by the respondents. An interview took 40 to 50 minutes in average. The respondent was compensated by non-monetary goddies as a reward for participating. Table 1 summarised brief characteristics of the respondents in this study. 
Table 1: Characteristics of Respondents

\begin{tabular}{ccccc}
\hline Respondent & Designation & Age & $\begin{array}{c}\text { Work Experience } \\
\text { (year) }\end{array}$ & $\begin{array}{c}\text { Interview Duration } \\
\text { (minute) }\end{array}$ \\
\hline 1 & $\begin{array}{c}\text { Supervisor at a } \\
\text { palm oil } \\
\text { plantation } \\
\text { Cheif clerk at a } \\
\text { palm oil } \\
\text { plantation } \\
\text { Assistant }\end{array}$ & 67 & 48 & 50 \\
3 & 33 & 37 & 40 \\
manager worker & & 9 & 30 \\
\hline
\end{tabular}

\section{Site Visit}

Site visit was conducted on November 15, 2019 and December 13, 2019. The site visit followed the procedures from Lawrenz, Keiser and Lavoie (2003). The aim for the site visit is to gather information about the evaluation object, in this case the former Morib Airfield, in order to prepare testimony addressing the purpose of the site visit. The site visit enables researchers to understand more clearly the micro-location of the former airfield site: the visibility and prominence of the site, the current terrain, the current land use, and the access to the site. For a bird's-eye view on the site, a drone (model DJI Phantom 3 Advance) and a high-resolution camera (model Canon 6D) were used. Drone with high-resolution cameras have the advantage of capturing the terrain from a so-called bird's eye view with high longitudinal and lateral accuracy (Krajewski, Bock, Kloeker\& Eckstein, 2018). The site visit was recently visited and reported in The Star online, on its interview results relating to a small flight landing area at Kelanang Estate in Banting. Mathews, one of the respondents, in his statement claimed that his father P.C. Mathews, had witnessed the landings on Malayan soil and had stepped forward to help some of the soldiers when operation zipper took place in Morib seashores (Sheela, 2020).

\section{RESULTS AND DISCUSSIONS}

With regards to both profiles of respondents, there was a long gap period of time between respondents and the event of World War II. Respondent 1 was born 7 years after the War. Meanwhile respondent 2 was born 17 years after the War. In terms of working in the estate plantation, respondent 1 started to work at the age of 17 years old in 1969. Respondent 2 only started to work in the same estate plantation at the age of 20 years old in 1982. The contents of the interview results from both respondents found that they have received information about the airfield based on verbal communication from their parents. Respondent 1 obtained the information from his father while respondent 2 received it from her mother and her grandmother.

Based on the content analysis from the two respondents, responses obtained were not directly related to the association of the Morib Airfield and Japanese occupation during World War II. Answers from the respondents were merely related after World War II events. The descriptions given by the respondents about the Morib Airfield were obtained verbally from their elders. Respondent 1 described how he saw a British airplane used the airfield for spraying fungus pesticide to the coconut trees through air. When he was asked about the association between Japanese army and the airfield, he stated that the airfield was constructed by the Japanese army. He was not sure what the purpose of the airfield construction was. He also added that when a British plantation company owned the airfield, the strip of the airfield was layered by granite. This was to ensure smooth airplane for takeoff and landing purpose. Furthermore, the British plantation company only utilized half of the strip for operation.

The views from respondent 2 was also quite similar with respondent 1 . She was aware of the knowledge of the airfield from her mother who was staying at the nearby village not far from the airfield location. She was told that once the Japanese surrendered in the World War 2, the British took 
over the airfield. Her view on the airfield was more on the British airplane that carried goods and distributed to villagers nearby.

Meanwhile, respondent 3 knew the existing of the formar airfield through his regular site visits and an old map from his company. He shared the map where the exact location of the airfield was located. Figure 3 shows the evidence of the site on Goldern Hope Plantations field. It was tagged and labelled as $\mathrm{OP} 89 \mathrm{~K}$.

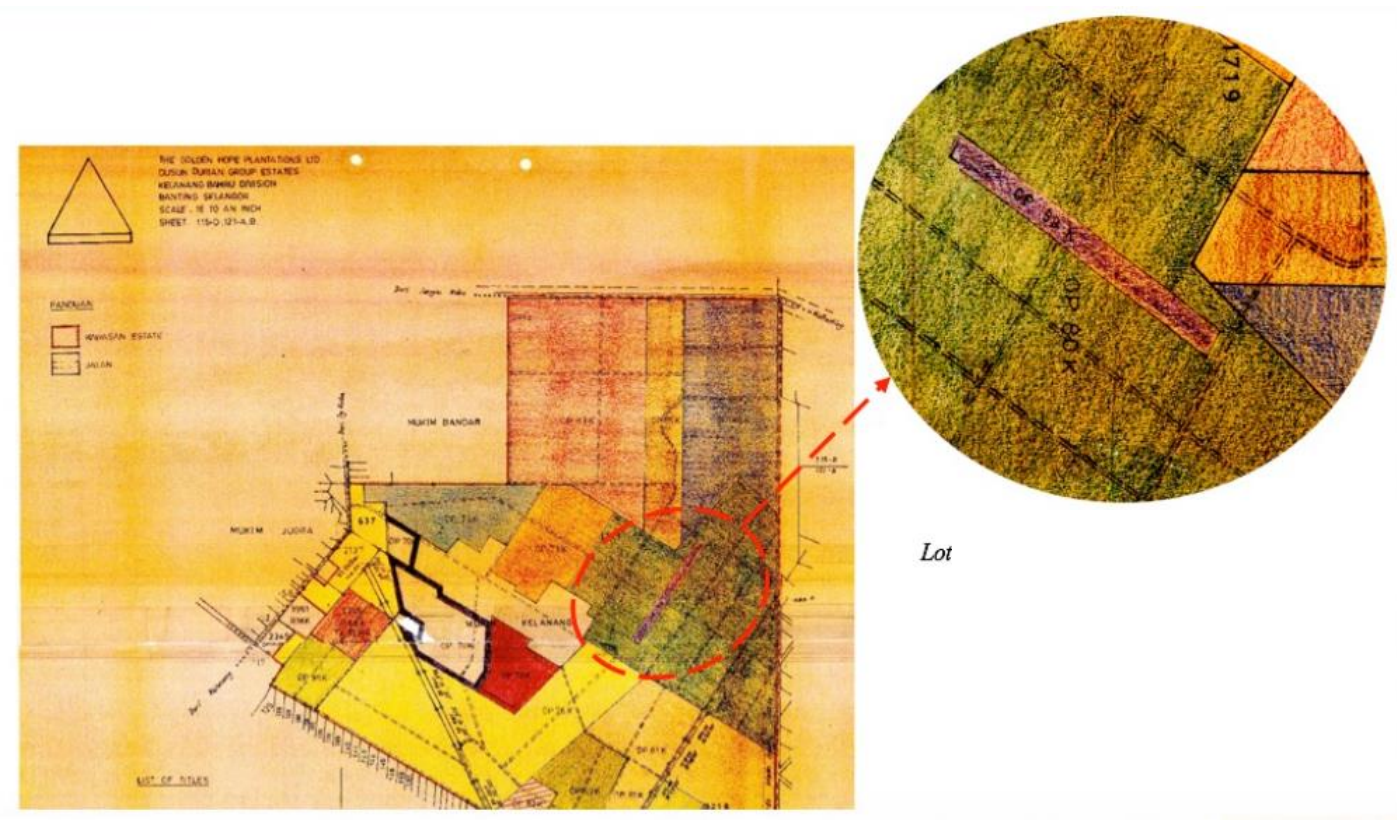

Figure 3: Lot 1719, The Golden Hope Plantations LTD, Kelanang Bahru Division: Field no. OP89K (Courtesy from: Sime Darby Plantation, Dusun Durian Plantations Office)

The outcome of the site visit revealed that the whole airfield is currently filled in with palm oil trees. It is no longer use for any pesticide operation through air. At this point of time, the palm oil plantation company does not have any intention to reuse back the airfield. The current view of the former airfield is shown in figure 4 and 5. Referring to figure 4 and 5, there is no trace of the remaining airfield. It is filled with palm trees. The land of the former airfield now is fully owned by a private palm oil plantation company. This land-use change from airfield to agriculture land can be viewed as the best use of the land from the perspective of the government authority (Gallent et al., 2000). Hence it can be stated that the status of this former airfield as cease operation.

This study also showed that information about the Morib Airfield during the Japanese occupation is not as reliable since all the respondents were born after the World War 2 period. In addition, the content analysis from the respondents was more on the description of the airfield after World War 2. This shows that the source for the association between the airfield and the Japanese occupation still needs to rely on the secondary sources (for example see Grehan and Mace, 2014; Bose, 2012; Warwick, 2007). However, majority of these secondary sources are from books and newspapers. Only one of the secondary sources is from the academic journal and one also from the Government source. Despite the lack of information needed for the findings to associate between the airfield and the Japanese occupation, this study contributes to the academic knowledge perspective. It can be used as a precedence for future researchers as a foundation to extend the study about the airfield.

From the sources of information (literature) that have been found and gathered for this study, at present there is still lacking academic literature review for the airfiled. Table 2 summaries the findings of literature review for Morib Airfield. 
Table 2: Summary of Literature for Morib Airfield

\begin{tabular}{|c|c|c|}
\hline Category of Literature & Number Found & Source \\
\hline Non-fiction book & 5 & $\begin{array}{l}\text { Grehan and Mace (2014); } \\
\text { Bose (2012); } \\
\text { Warwick (2007); } \\
\text { Holder (2005); } \\
\text { David (2000). }\end{array}$ \\
\hline Newspaper & 3 & $\begin{array}{l}\text { Singapore Free Press (September 10, } \\
\text { 1947.p.8); Malaya Tribune (September 23, } \\
\text { 1947.p.6); } \\
\text { Morning Tribune (September 12, 1947.p.15) }\end{array}$ \\
\hline Journal & 1 & Price and Robertson (1947) \\
\hline Government document & 1 & London Gazzette, 1951 \\
\hline Company document & 1 & Golden Hope Plantation \\
\hline $\begin{array}{l}\text { CIO, HQ, South East Asia Air } \\
\text { Command }\end{array}$ & 1 & Airfield Schedule: Morib Landing Ground \\
\hline
\end{tabular}

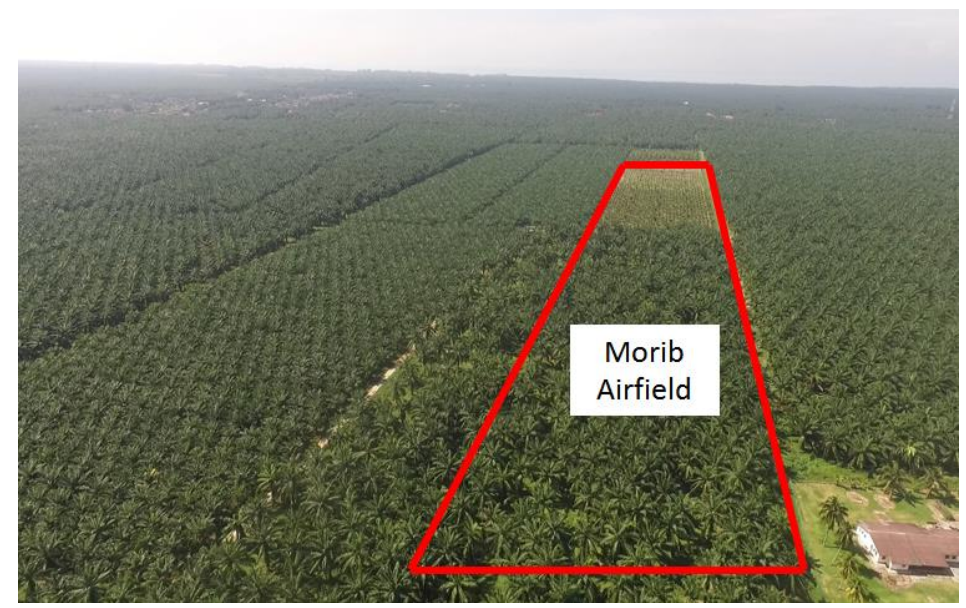

Figure 4: The view of former Morib Airfield from air Source: Author on site photo collection using drone DJI Phantom 3

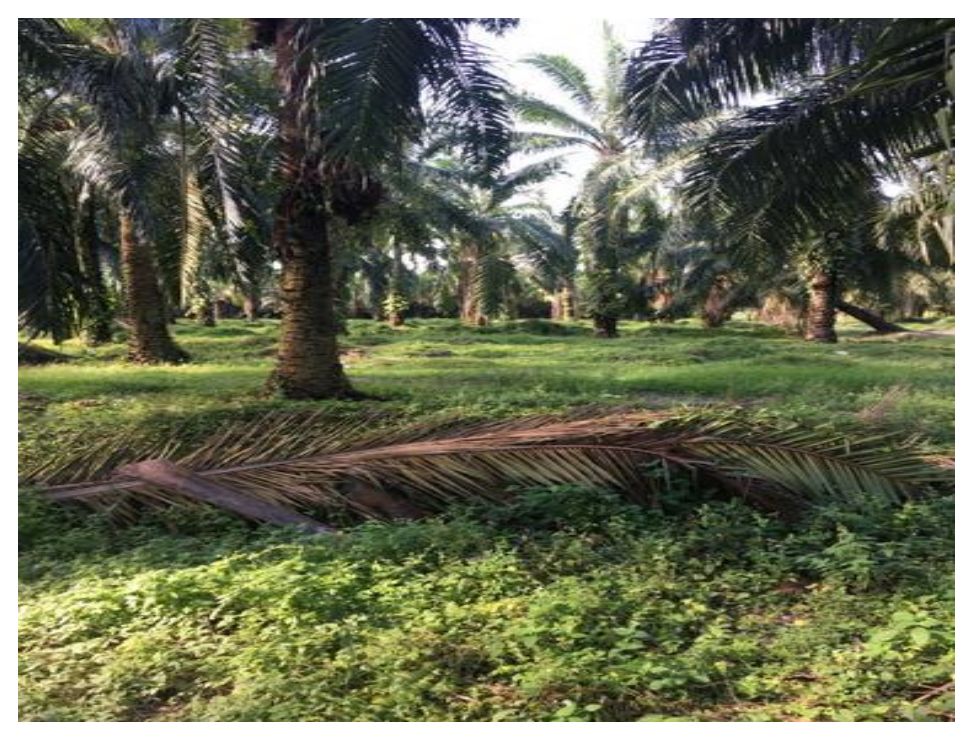

Figure 5: The view of former Morib Airfield from land Source: Author on site photo collection using Canon Camera 6D model 


\section{CONCLUSIONS AND FUTURE RESEARCH}

Based on the responses gained through this exploratory study, it clearly shows that the present study contributes to the extension of knowledge for a literature review pertaining to the Morib Airfield during pre- and post-World War II. The study also provides the current view of the land in use from the former airfield. In terms of the output from the in-depth interview, it was found that the content of the analysis provided more descriptions on the post-World War II. In addition, the information about the airfield during the Japanese occupation was merely from the verbal interactions of their elders. The three respondents of the present study were from Dusun Durian Estate, Sime Darby Plantion supervisor, senior assistant and clerk who have worked at the plantation for more than 15 years. Stories obtained from generation to generation have made them aware of the existence of the structure. This was followed with a recent interview by the STAR reporter who had interview another respondent who obtained stories from his late father in September 2020. Initiatives have been taken to ensure information pertaining to the airfield is remembered not only among people who stay around the area. Therefore, the recordings of this interview have developed a formal record of this forgotten airfield, which previously was significant for soldiers' operation before independence. Future research needs to have more depth in terms of scientific and historic elements of the airfield, such as tests on soil, water, and stones.

\section{ACKNOWLEDGEMENTS}

The researchers would like to acklowledge the courtesy of the Estate Manager, Tuan Ahmad Sharifuddin Zakaria from Sime Darby Plantation, Dusun Durian Estate Office for participating in the interview process as well as to provide access to the site, and documentations on site map.

\section{REFERENCES}

Bose, R. (2012). Singapore at War: Secrets from the Fall, Liberation \& Aftermath of WWII. Marshall Cavendish Editions, Singapore.

Chelaeh, M., Aman, R., Hamid, S., Othaman, N., Ruslan, S., Abu Bakar, N., Salam, R., Fadzil, F.H. \&Sinur, D. (2017). Discovery of linguistic features in Jugra dialect: Structural phonology analysis. Journal of Social Science and Humanities, 12(3), online.

Chief Information Officer, Headquarters: Air Command South East Asia (1945). Malaya Map Ref: Airfield Schedule: Morib Landing Ground. 1" HIND 1035 3/F/1 \& 3/F/2.

Clearing Morib airfield of bombs. (1947, September 12). Morning Tribune.

Clearing Morib airfield of mortar bombs. (1947, September 10). The Singapore Free Press.

David, D. (2000). Dennis 'Hurrucane’ David: My Autobiography. Grub Street, London.

Explosives found near airfield. (1947, September 23). Malaya Tribune.

Grehan, J. \& Mace, M. (2014). Far East Air Operations 1942 - 1945: Dispatches from the Front. Pen \& Sword Aviation, Barnsley, South Yorkshire.

Holder, R. W. (2005). Eleven Months in Malaya: September 1945 to August 1946. Editions Didier Millet: Kuala Lumpur.

Krajewski, R., Bock, J., Kloeker, L. \& Eckstein, L. (2018). The high D Dataset: A Drone Dataset of Naturalistic Vehicle Trajectories on German Highways for Validation of Highly Automated Driving Systems. IEEE 21st International Conference on Intelligent Transportation Systems (ITSC), Maui, Hawaii, USA, November 2018.

Lawrenz, F., Keiser, N. \& Lavoie, B. (2003). Evaluate site visits: A methodological review. American Journal of Evaluation, 24(3), 341-352.

Map of Dusun Durian Plantation.The Golden Hope Plantations Limited, Dusun Durian Estates. Kelanang Bahru Division, Banting Selangor.

London Gazette (1951). Supplement to the London Gazette, 13 April 1951.

Price, D.W. \& Robertson, J.R. H. (1947). Indian beach groups in the landings in Malaya. The Royal Engineers Journal, 61, 288-305. 
Sheela, C. (2020). Remembering the British Indian Army's fight during the Japanese Occupation of Malaya. The Star Online. Retrieve from https://www.thestar.com.my/lifestyle/living/2020/09/30/remembering-thebritish-indian-army039s-fight-during-the-japanese-occupation-of-malaya on September 30, 2020.

Tamrin, K.M. (1977). Satu nota tentang Kelanang dalam tahun 1880an dan 1890an. Malaysia in History, 20(1), 21-23.

Vincent, R.K. \& Jennings, D. L. (2004). A fout-state field evaluation of the Boeing Landing Suitability Index (BLSI) for automatically mapping candidate aircraft operating sites in natural terrain from LANDSAT TM data. Journal of Terramechanics, 41 (2-3), 151-162.

Warwick, N. W. M. (2007). Constant Vigilance: The RAF Regiment in the Burma Campaign. Pen \& Sword Aviation, Barnsley, South Yorkshire.

\section{Interviewee:}

Lailah, S. A. (2019, December 13). Personal Interview. Reganathan, A. (2019, December 13). Personal Interview. Rosnizam, R. (2019, December 13). Personal Interview. 